\title{
Designing a Student Counseling Guidance Information System at SMA Negeri 1 Batang Kapas Using the Codeigniter (CI) Framework
}

\author{
Reka Sabna Citra1,", Supratman Zakir ${ }^{2}$
}

1,2Informatics and Computer Engineering Education IAIN Bukittinggi, Bukittinggi, Indonesia

\begin{tabular}{l} 
Article Information \\
\hline Article History: \\
Accepted by Editor: May 05, 2021 \\
Final Revision: June 11, 2021 \\
Published Online: June 30, 2021 \\
Keywords \\
\hline Counseling Guidance \\
Framework \\
Codeigniter \\
R\&D \\
$4 \mathrm{D}$ \\
Correspondence
\end{tabular}

E-mail: rekasabnacitra07@gmail.com*

\begin{abstract}
A B S T R A C T
This research is conducted because of the need for an information system about how each student's learning development and student behavior were needed, so that Counseling Teacher (BK) was needed. Counseling Teacher (BK) SMA Negeri 1 Batang Kapas is a school directly related to student discipline that requires a computerized information system to operate data collection so that it is more optimal. It is carried out because the Counseling Guidance in schools has not used a computerized system in carrying out its work activities, the school still uses a conventional system such as in making attendance reports and archiving student violation data still using a portfolio so it seems that they use a lot of paper, many points of violation are not accumulated because of recording is still manual, so that sanctions are not appropriate and there is no valid and effective database in data management. It is the background for researchers to design a student counseling guidance information system using the CodeIgniter $(\mathrm{CI})$ framework. The methodology used in the research is the type of research and development research commonly called R\&D, which is research to create the desired program and test the program's effectiveness. The research model chosen is the $4 \mathrm{D}$ version, namely define, design, develop, and disseminate. This model uses the waterfall. Based on the results of the product test, the validity results of several computer experts were 0.91 (very valid), the results of the practicality test of two Counseling Teacher and one homeroom teacher obtained an average result of 0.91 , which is very practical, while for the effectiveness test it was obtained value 0.91 (very high).
\end{abstract}

\section{Introduction}

According to Article 1 paragraph 6 of Law No. 20 of 2003, the existence of counselors in the national education system is recognized with an educational qualification in line with the qualifications of teachers, lecturers, civil servants, and tutors [1]. The counselor's role in preparing students for higher education is to realize students can compete with the world of work and are of high quality by creating student character and focusing students on sharpening students' intelligence in education.

This role can be influential if the counseling guidance is supported by a computer system in managing data effectively in schools. Counseling Teacher (BK) SMA Negeri 1 Batang Kapas is a school directly related to student discipline that requires a computerized information system to operate data collection so that it is more optimal. It is crucial because the Student Counseling Guidance field at SMA Negeri 1 Batang Kapas 
has not used a computerized system in carrying out its work program. The school still uses a conversion system such as making attendance reports and archiving student violation data, still using portfolios, so it seems that they use a lot of paper and lots of paper. Violation points do not accumulate because the recording is still manual, which causes the sanctions to be inappropriate. The inappropriateness of the sanctions given can influence the results of students' personalities and morals which are also the leading indicators for each student, while data processing is carried out to obtain the desired data. Attendance reports and data archiving violations committed by students are included in the data set. Data collection is the collection of data as a whole and significant information that is carried out to increase student needs [2]. The data collection is part of the activities supporting the Counseling Guidance service, the data is used as a reference for the preparation of the BK program by analyzing the attendance and violations committed by students, which are a form of discipline, so it can be the basis for the birth of the Counseling Guidance service program, one of which is information services about discipline.

\section{Method}

The method used in the research is research and development which is commonly called R\&D, to create a desired program and test program effectiveness. The research model chosen is the $4 \mathrm{D}$ version, namely define, design, develop, and disseminate [3]. The define phase is a step to define a product that will be made by finding information about the ongoing system at school so that from the ongoing system problems can be found. The design phase is the stage for drawing the flow and the design that will be made for the program based on the problems raised in the definition stage based on the school's needs. Furthermore, the develop/development phase is the stage in building/developing the system using the waterfall model from the SDLC (System Development Life Cycle) development model. Then the dissemination phase is the stage of distributing the program created to users. Figure 1 is a schematic of the research stages.

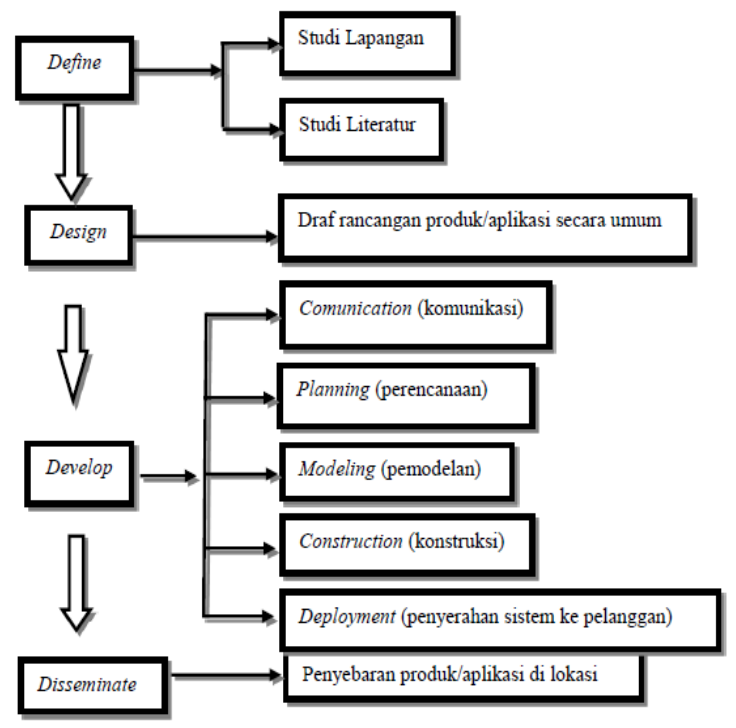

Figure 1. Research Process

The testing phase of the research is validity test, feasibility/practical test and effectiveness test as a tool for program testing, namely a questionnaire. The questionnaire consists of a validity test questionnaire, a practicality test questionnaire and a questionnaire to test the program's effectiveness.

\subsection{Validity test}

Validity tests need to be carried out to create programs that are ready to be tested and of good quality if later used by users. It is done by filling out a questionnaire that has been made to be assessed by the appointed validator. This validity test is guided by the following Aiken's V statistical formula. 


$$
\mathrm{v}=\sum \mathrm{s} /[\mathrm{n}(\mathrm{c}-1)]
$$

With $\mathrm{s}=\mathrm{r}-\mathrm{lo}$, where lo is the smallest number of validity searches and $\mathrm{r}$ is the value of the validator, $\mathrm{C}$ is the highest number of validity searches and $\mathrm{n}$ is the value of the validator [5]. The value of the validity criteria can be seen in Table 1 .

Table 1. Criteria for Determining Validity

\begin{tabular}{cc}
\hline Percent $\%$ & Criteria \\
\hline $0,6<$ & Invalid \\
$>=0,6$ & Valid \\
\hline
\end{tabular}

\subsection{Practical Test}

The results of the practicality test were obtained from the assessment of the questionnaire on the Design of Student Counseling Guidance Information Systems at SMA Negeri 1 Batang Kapas Using the Codeigniter (CI) Framework. The assessment will receive a response from the Counseling Guidance Teacher as a student counselor. This assessment uses the following Moment Kappa formula.

$$
\underset{w}{k=(\rho-\rho e) /(1-\rho e)}
$$

$\mathrm{K}$ shows the program effectiveness of the Moment Kappa is the obtained scale, calculated by dividing the number of scores given by the examiner by the maximum number of scores. e is the unrealized scale, obtained by subtracting the maximum number of examiners' scores divided by the total number of maximum scores. The decision categories based on kappa moments are: $0.81-1.00$ very high; High 0.61-0.80; Average 0.41-0.60; 0.21-0.40 weak; 0.01-0.20 is very low and and $<0.00$ is impractical

\subsection{Effectiveness Test}

The effectiveness test is the final stage of the product being tested. The effectiveness test is the result of measuring the equivalence of the initial objectives with the program results. Analysis of the effectiveness of the Design of Student Counseling Guidance Information System at SMA Negeri 1 Batang Kapas Using the Code igniter (CI) Framework is determined by assessing the questionnaire filled out by students. The effectiveness test is carried out by referring to the statistical formula of Richard R. Hake (G-Score) below.

$$
\langle g\rangle=\frac{(\%\langle S f\rangle-\%\langle S i\rangle)}{(100-\%\langle S i\rangle)}
$$

Description:

$$
<\mathrm{g}>\text { : G-Score }
$$

$<$ Sf $>$ : Final Score

$<\mathrm{Si}>$ : Initial Score

The criteria are as follows: (1). "High-g" is high effectiveness if it has $(<\mathrm{g}>)>0.7$; (2). "Medium-g" is moderately effective if it has $0.7>(<\mathrm{g}>)>0.3$; (3). "Low-g" is low effectiveness if it has $(<\mathrm{g}>)<0.3$. 


\section{Results and Discussion}

\subsection{Define}

The defining stage in this research is to find information about the current system; researchers need to know what problems Counseling Teacher face, especially in counseling guidance, so that researchers can easily translate what problems are happening and the needs that are considered necessary for the school. From the definition, the researchers found the problem faced by the school, namely the absence of a data collection system in the field of counseling guidance which was carried out using a computer and the absence of a database so that the recording of student violation points was not recorded in a structured manner, resulting in sanctions given to students who violated inappropriateness as well as recording on absenteeism. Which is still manual by using a portfolio, resulting in frequent data loss, while schools always need accurate attendance.

\subsection{Design}

In this design stage, the researcher designed an information system based on the school's needs to facilitate teachers' Counseling Teacher in managing BK data. In this phase, the researcher designs a flow that will facilitate the program description that will be made. So, the design is structured and the basic description of a program.

\subsection{Develop}

\subsubsection{Project Innitiation}

Counseling Guidance in schools does not yet have an information system in a recap of attendance and recording violations. Recap attendance and recording of violations still use the manual method in data collection so that data on violations and attendance is often lost. If there is data loss in the recording of violations, it will result in counseling guidance services because the services provided to students follow the data set presented such as attendance and violations committed by students.

\subsubsection{General System Design}

a) Use case diagram

Use case diagram is a description of the behavior of the program that was built. The use case describes the reciprocal relationship of one or several actors to be designed [8]. Figure 2 is a use case diagram of the student counseling guidance information system at SMA Negeri 1 Batang Kapas.

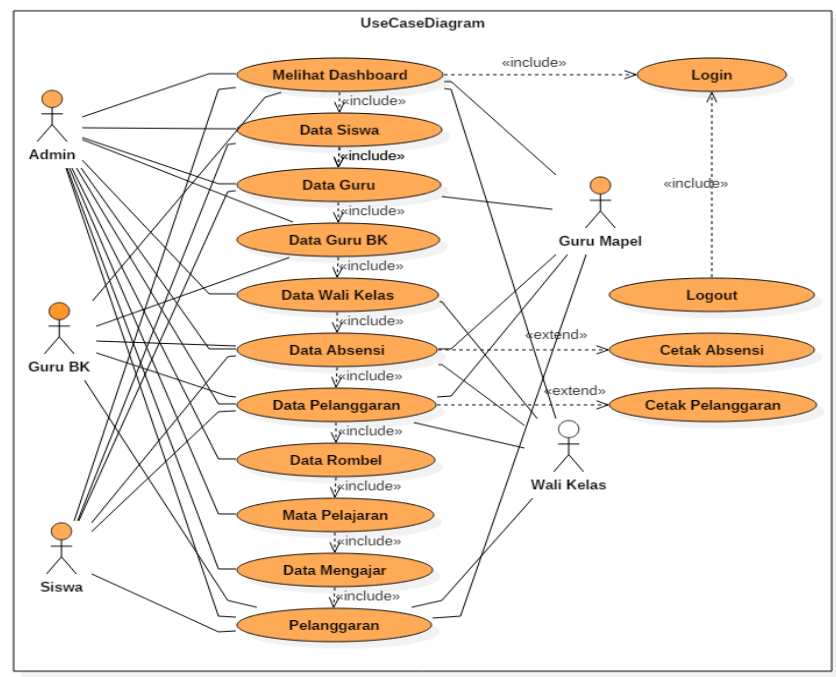

Figure 2. Use Case Diagram of Student SIBK 
Based on Figure 2, it can be seen that there are four actors, namely admin, user (student/parent), teacher and class representative. In the admin actor there are 13 use cases, namely logging in, viewing dashboards, student data, teachers, school counselors, homeroom teachers, attendance data collection, violation data, study group data (rombel), subjects, teaching data, violations, and logout. User actors (students/parents) consist of 7 use cases: login, viewing dashboard, student data, attendance data, violation data, violation, and logout.

b) Activity diagram

Activity Diagram describes the activities of the actors in the program that was built [9]. Activity diagrams describe the overall program activities created, from the initial to how they end. Figure 3 is a research activity diagram.

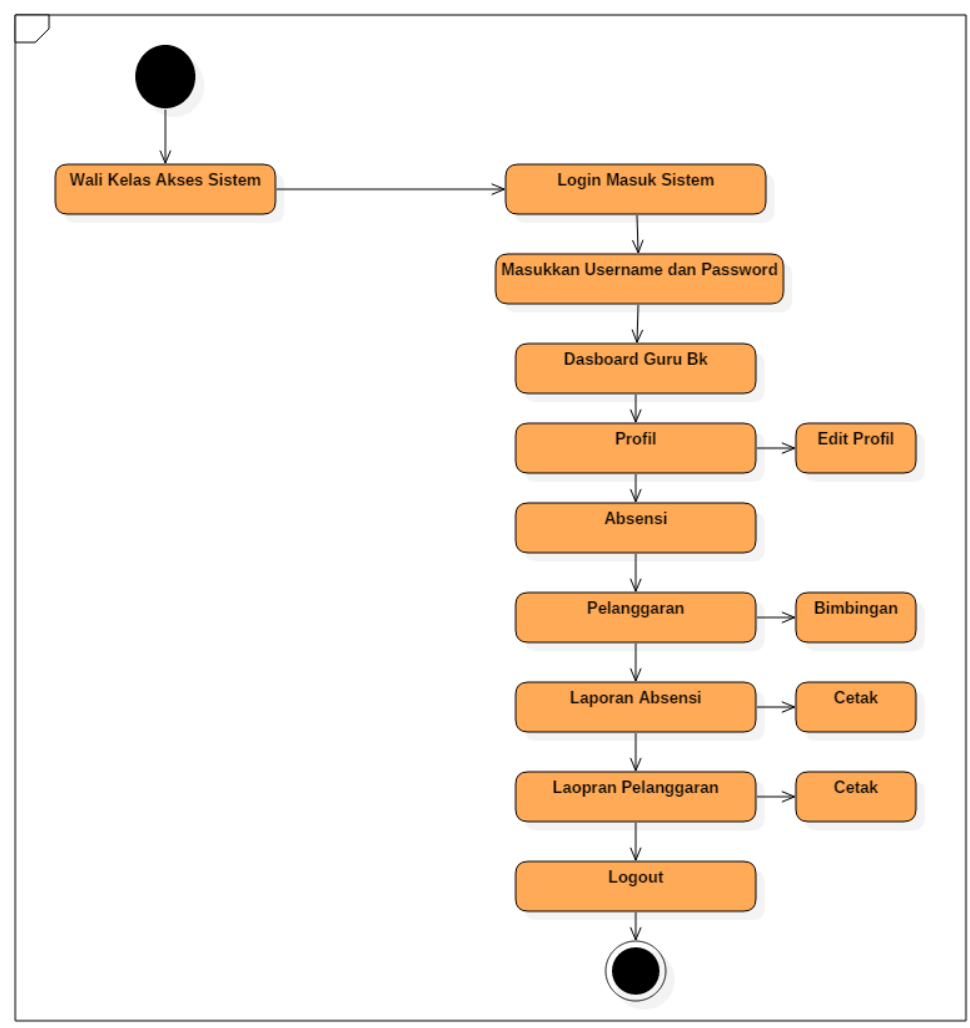

Figure 3. Student SIBK Activity Diagram

c) Class diagram

Class diagrams are classes that are created from objects after they are created that are interconnected between one or more classes [10]. Figure 4 below is a research class diagram. 


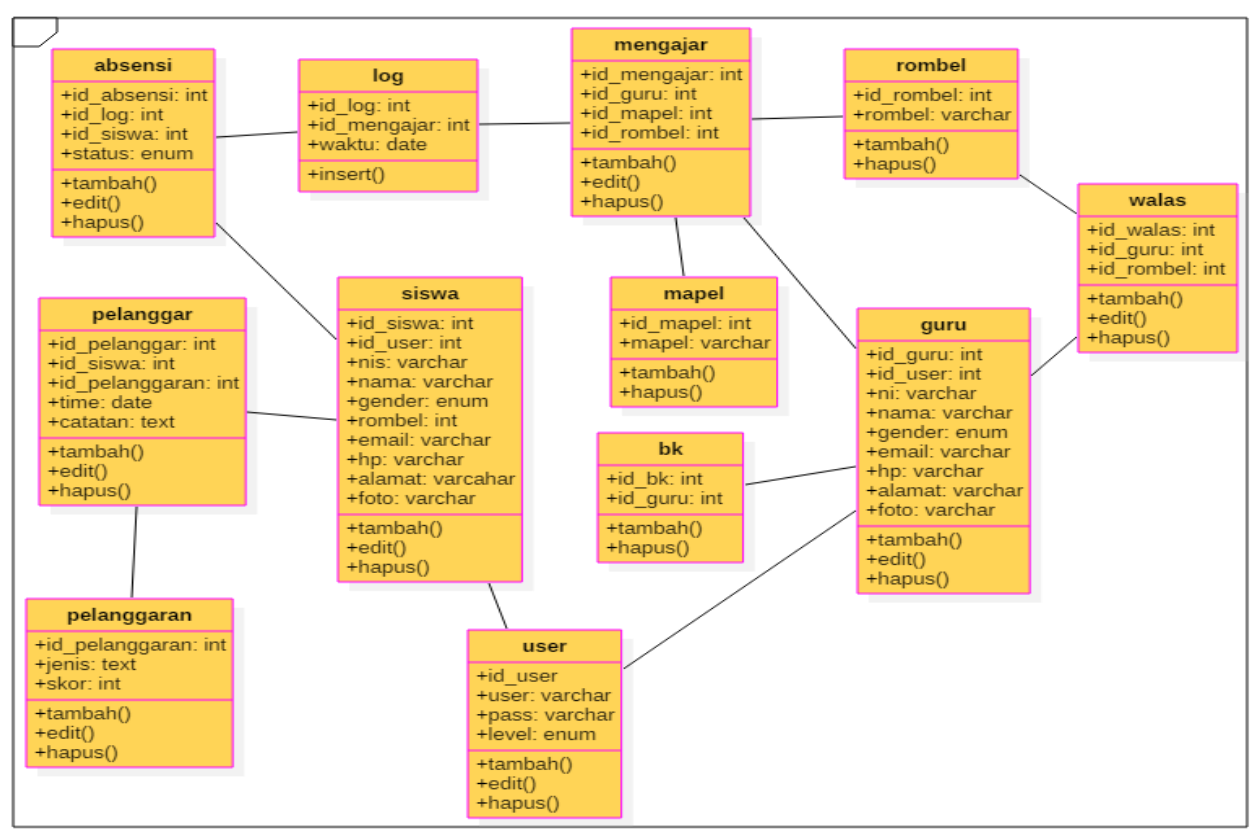

Figure 4. Class Diagram of Student SIBK

\subsubsection{Detailed System Design}

a) Input Design

The input design consists of a login page in Figure 5, an attendance page in Figure 6, and a violation page in Figure 7.

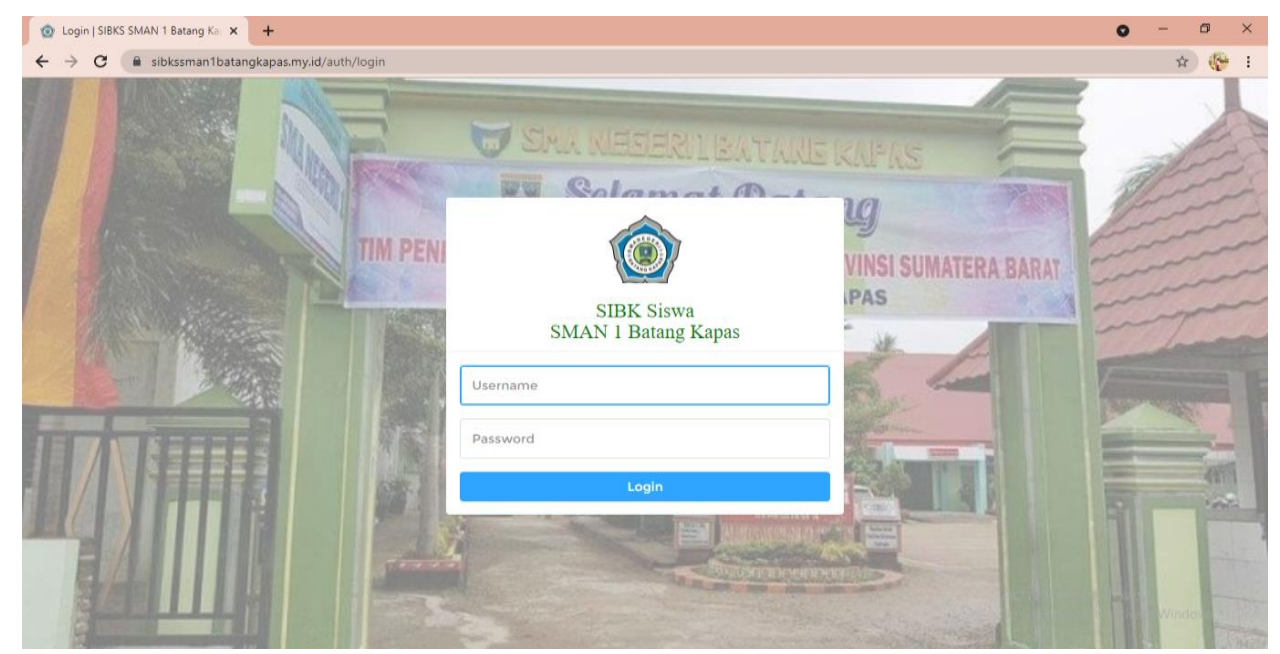

Figure 5. Login page 

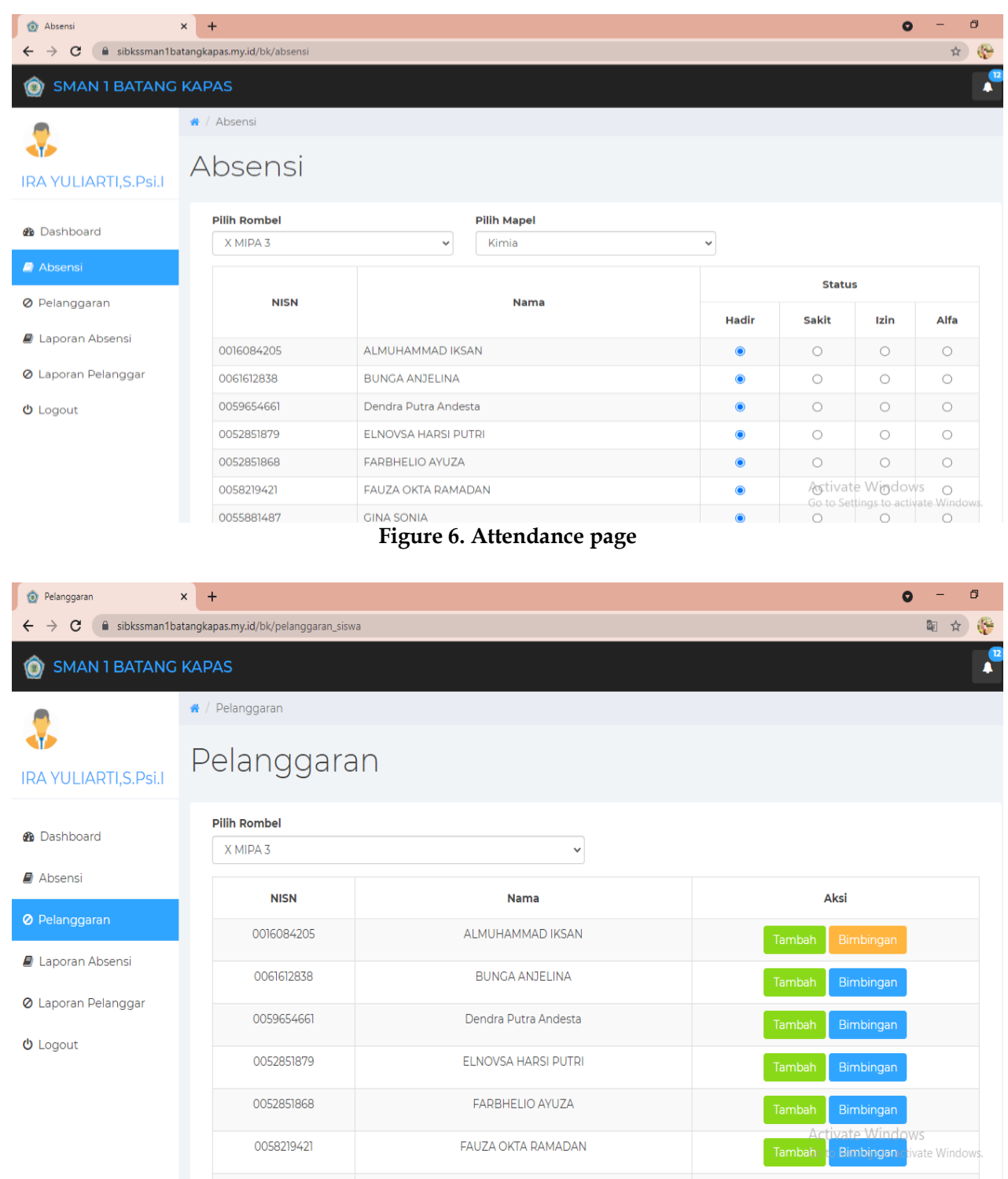

Figure 7. Violation page

\section{b) Output Design}

The output design consists of an attendance report in Figure 8 and a violation report in Figure 9.

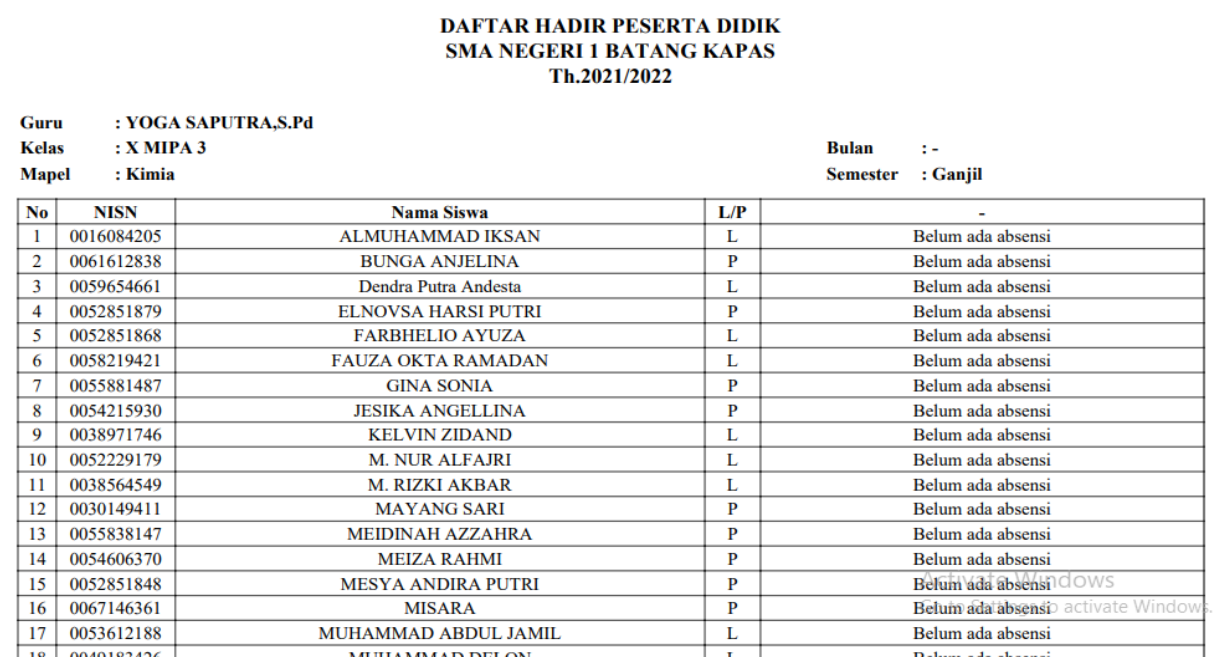

Figure 8. Attendance Report 


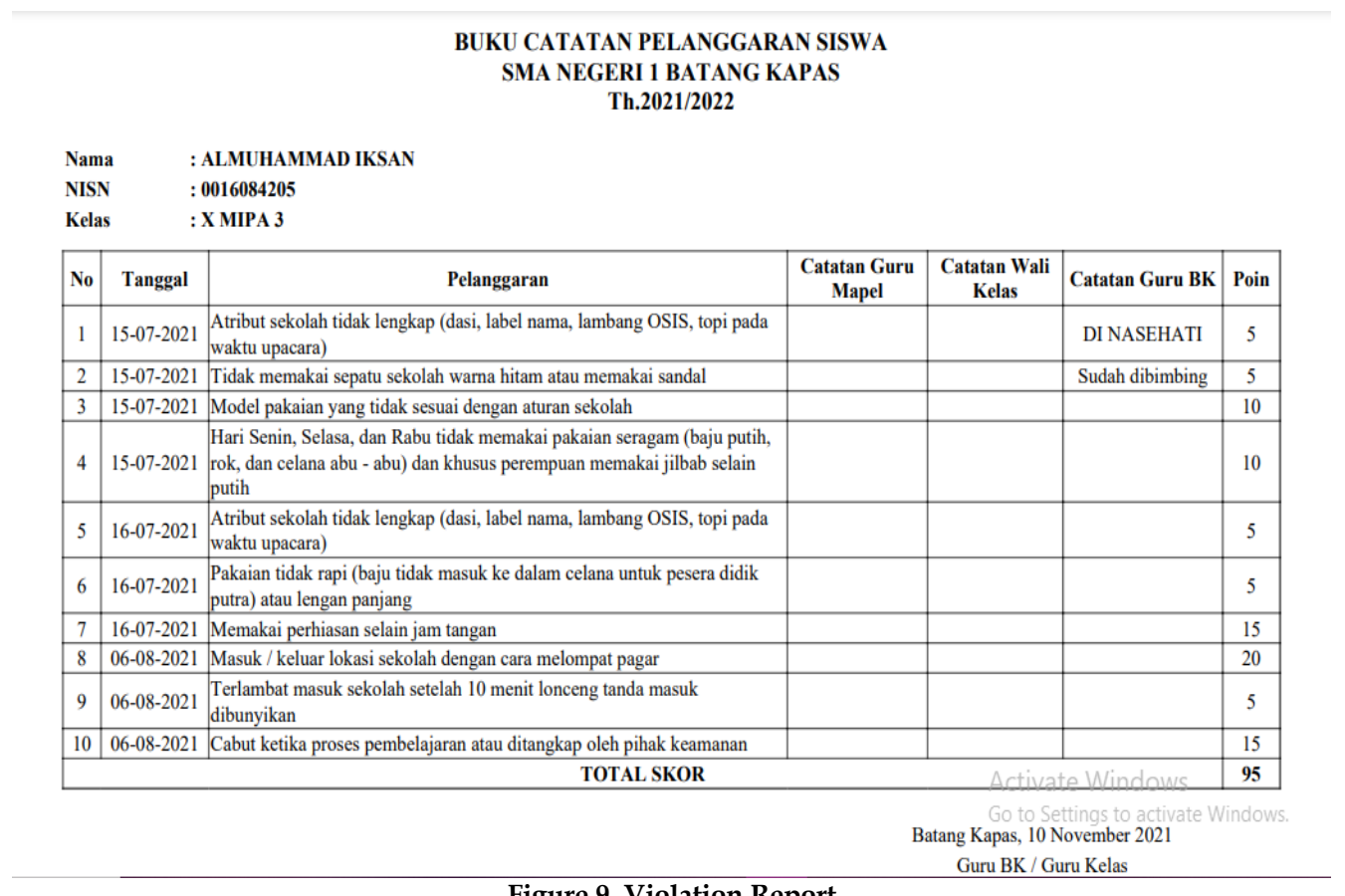

\subsection{Disseminate}

The distribution phase is the final program utilization phase obtained in an online student counseling information system that can be accessed via a web browser. The distribution stage is carried out by submitting the program to schools and parties involved. The validity, practicality, and effectiveness of using this counseling guidance information system by paying attention to and using the product and allowing users to provide evaluations, suggestions, and comments to complete the final product development.

\subsection{Product Test}

\subsubsection{Validity test}

In order to produce quality programs that users can use and to find the level of accuracy of the programs made, it is necessary to carry out validity tests. The program can be used and successful if the assessment given follows the program's accuracy. The results of the validity test that the author got from the three validators by referring to the questionnaire and the formula that had been determined, the authors got a value of 0.91 . This states that the program created is very valid.

\subsubsection{Practical test}

Testing the program using a test in the form of a questionnaire on the student counseling guidance information system which is carried out to find out whether the product made it easy to use or not to get practical test results. The practicality test that was carried out on the three practicality examiners that the authors got using a predetermined formula was 0.91 (very practical), thus the Design of Student Counseling Guidance Information System at SMA Negeri Batang Kapas Using Codeigniter (CI) that the researchers made was practical to use by the user.

\subsubsection{Effectiveness test}

After calculating through effectiveness analysis using the formula specified in the Design of Student Counseling Guidance Information System at SMA Negeri 1 Batang Kapas Using the Codeigniter (CI) 
Framework, the results are very effective for use by users, namely 0.91 which is determined by the assessment of the questionnaire completed by the teacher. Subjects, homeroom teachers and students.

\section{Conclusion}

The Information System for Student Counseling Guidance at SMA Negeri 1 Batang Kapas uses the CodeIgniter Framework, which can be accessed on a web with the URL sibkssman1batangkapas.my.id. This system is designed using the PHP programming language and the CodeIgniter framework and is assisted by a MySQL database. Some additional applications that help its development are XAMPP, Google Chrome browser, Sublime text editor, and Bootstrap CSS Framework as a system display.

This system is designed to make it easier for schools, especially Counseling Teacher, in dealing with student problems at school, such as attendance reports and student violation reports. In addition, Counseling Teacher do not need to check the data to their respective classes because the teacher inputs each data with this information system. Subject teachers will be received directly by Counseling Teacher through notifications to make their performance and result more valid, practical, and effective.

Based on the validity test of 3 computer experts, the system was declared very valid with an average of 0.91. Furthermore, the practicality test was carried out on two Counseling Teacher and one walas, the system was declared very practical with an average of 0.91 . Finally, the effectiveness test was carried out on two sane people, two subject teachers, and three students; the system had a very high effectiveness score with an average of 0.91 . Based on the product test results, it can be concluded that the resulting product is very valid, practical, and effectively used by the school.

\section{References}

[1] H. Kamaluddin, “Bimbingan dan Konseling Sekolah,” J. Pendidik. dan Kebud., vol. 17, no. 4, p. 447, 2011.

[2] A. Prasetyoaji and S. Handayani, "Sistem Himpunan Data Berbasis Web Dalam Layanan Bimbingan dan Konseling," konseling GUSJIGANG, vol. 3, no. 2, pp. 180-185, 2017.

[3] A. N. Khomarudin, L. Efriyanti, and M. Tafsir, "Pengembangan Media Pembelajaran Mobile Learning Berbasis Android Pada Mata Kuliah Kecerdasan Buatan," J. Educ. J. Educ. Stud., vol. 3, no. 1, pp. 1-87, 2018.

[4] P. Setiawan, Sulistiowati, and J. Lemantara, "Rancang Bangun Aplikasi Pengolahan Data Evaluasi Proses Belajar Mengajar Berbasis Web Pada STIKES Yayasan RS. Dr. Soetomo Surabaya," Jsika, vol. 4, no. 2, pp. 1-6, 2015.

[5] S. M. A. N. Banuhampu, D. Of, E. A. In, and B. State, "Perancangan Aplikasi E-Discussion Pada SMA Negeri 1 Banuhampu," vol. 11, no. 2, pp. 118-130, 2019.

[6] R. Sagita, F. Azra, and M. Azhar, "Pengembangan Modul Konsep Mol Berbasis Inkuiri Terstruktur Dengan Penekanan Pada Interkoneksi Tiga Level Representasi Kimia Untuk Kelas X SMA," J. Eksakta Pendidik., vol. 1, no. 2, pp. 25-32, 2017.

[7] M. Ikhbal and H. A. Musril, "Perancangan Media Pembelajaran Fisika Berbasis Android," Inf. Manag. Educ. Prof., vol. 5, no. 1, pp. 15-24, 2020.

[8] S. Rahmawati and Jarwo, "Perancangan Aplikasi Sistem Informasi Bimbingan Konseling SMA Pomosda Berbasis Web dengan PHP 5.437 dan MySQL 5.5.42," Cyber-Techn, vol. 14, no. 02, pp. 22-32, 2020.

[9] A. Hendini, "Pemodelan UML Sistem Informasi Monitoring Penjualan dan Stok Barang (Studi Kasus: Distro Zhezha Pontianak)," J. Khatulistiwa Inform., vol. 4, no. 2, pp. 107-116, 2016.

[10] L. Najmi, E. Hutabri, and A. Pratam, “E-Konseling Siswa Pada Sekolah SMA N 4 Pariaman," Edik Inform., vol. 5, no. 2, pp. 10-16, 2019. 